\title{
Critical reflections on experiential learning for food justice
}

\author{
Leslie Gray, ${ }^{\mathrm{a}, *}$ Joanna Johnson, ${ }^{\mathrm{b}}$ Nicole Latham, ${ }^{\mathrm{c}}$ Michelle Tang, ${ }^{\mathrm{d}}$ Santa Clara University \\ Ann Thomas, ${ }^{e}$ University of California at Santa Cruz
}

Submitted 1 December 2011 / Revised 13 February and 9 April 2012 / Accepted 24 May 2012 / Published online 19 June 2012

Citation: Gray, L., Johnson, J., Latham, N., Tang, M., \& Thomas, A. (2012). Critical reflections on experiential

learning for food justice. Journal of Agriculture, Food Systems, and Community Development, 2(3), 137-147.

http://dx.doi.org/10.5304/jafscd.2012.023.014

Copyright (C) 2012 by New Leaf Associates, Inc.

\section{Abstract}

This essay will reflect on Santa Clara University's (SCU) forays into experiential learning around food

\footnotetext{
a, * Corresponding author: Leslie Gray, Executive Director, Environmental Studies Institute, Santa Clara University; 874 Lafayette Street; Santa Clara, California 95053 USA; +1-408551-7054; 1cgray@scu.edu

b Joanna Johnson, Director, Bronco Urban Gardens Program, Environmental Studies Institute; Santa Clara University; Santa Clara, California USA; +1-408-551-3000 x6453; j1johnson@scu.edu
}

c Nicole Latham, AmeriCorps Volunteer, Bronco Urban Gardens Program, Environmental Studies Institute, Santa Clara University; Santa Clara, California USA; +1-408-5517086; nicole.i.latham@gmail.com

d Michelle Tang, AmeriCorps Volunteer, Bronco Urban Gardens Program, Environmental Studies Institute, Santa Clara University; Santa Clara, California USA; +1-408-5517086; mang@scu.edu

e Ann Thomas, Environmental Studies Program, University of California at Santa Cruz; Santa Cruz, California 95064 USA; +1-925-878-1567; anngthomas@gmail.com justice through the Bronco Urban Gardens (BUG) program. BUG works with urban schools and a community center in San José, California, using a garden-based education approach. This program emerged out of our student garden, The Forge. University student farms and gardens provide opportunities for students to learn how to grow, manage, and market food. At Santa Clara University, our half-acre ( 0.2 hectare) garden plays that role. However, because of our institution's commitment to social justice and a strong network of community partners, our campus garden has blossomed into a larger food justice outreach program. We will first discuss the motivation behind experiential learning for social justice and reflect on its connection to food justice. We then focus on several observations, challenges, and questions that have emerged out of our BUG experiences. Some of those observations involve the challenge of working with students and community partners where the interests of both groups must be served. We also explore what food justice means in this 
context, and what it means when a program expands beyond the committed few to an entire student body. By engaging in food justice with lowincome communities of color through innovative campus programs such as BUG, our students are likely to see the food system from a very different vantage point than if they stayed on campus, resulting in deep learning experiences and also benefits for communities.

\section{Keywords}

experiential learning, food justice, garden-based education, university agricultural education, urban agriculture

\section{Introduction}

University student farms and gardens provide opportunities for students to learn how to grow, manage, and market food. They also provide venues for students to reflect on sustainable agriculture and their own nested food systems (local, regional, national, international), often resulting in community action around sustainable foods both on and off campus. At Santa Clara University (SCU), our half acre ( 0.2 hectare) garden plays that role. This garden, dubbed the "Forge" as a nod to its history as the university's original blacksmithing site, provides a space to grow food as well as conduct trainings, classes and student project. Furthermore, because of our institution's commitment to social justice and a strong network of community partners, our campus garden has blossomed into a larger food justice outreach program. Out of the Forge garden, we have developed the Bronco Urban Gardens (BUG) program, which works with urban schools and a community center in downtown San José, California. Because of the new SCU core curriculum requirement of experiential learning for social justice, our program has an added goal: providing our undergraduate students with community placements around environmental and food justice. Our program staff and faculty use food justice and gardening to engage students critically with social justice issues. Gottlieb and Joshi (2010, p. 6) characterize food justice as seeking to ensure "that the benefits and risks of where, what, and how food is grown and produced, transported and distributed, and accessed and eaten are shared fairly." Food justice is a compelling concept that "resonates with many groups and can be invoked to expand the support base for bringing about community change and a different kind of food system" (Gottlieb \& Joshi, 2010 , p. 5). By engaging in food justice with lowincome communities of color through innovative campus programs such as BUG, our students are likely to see the food system from a very different vantage point than if they had stayed on campus, resulting in deep learning experiences and also benefits for communities.

The BUG program is part of a larger partnership, the Silicon Valley Health Corps, a Santa Clara County food justice collaborative that assigns AmeriCorps volunteers to 12 local organizations. The goal of the Silicon Valley Health Corps is to bring fresh fruits and vegetables and education to low-income residents of Santa Clara County. Santa Clara County, the heart of Silicon Valley, is generally considered to be an area of relative abundance and wealth, yet it also includes significant pockets of poverty. California Food Policy Advocates (2012) estimates that 33.5 percent of Santa Clara County adults lived in food-insecure households in 2010. Many low-income communities in Santa Clara County have little walkable access to grocery stores, few farmers' markets or community supported agriculture pick-up points, and a preponderance of unhealthy resources such as fast-food outlets and convenience stores (Public Health Law \& Policy [PHLP], 2010). The neighborhoods that BUG works in fit this pattern. Alma, Gardner, and Washington neighborhoods, informally known as "the triangle" where three opposing gang territories meet, are some of the lowest-income neighborhoods in San José. ${ }^{1}$ They have suffered from years of disinvestment and neglect, leaving them with liquor stores, fast food chains, empty lots, and freeways rather than grocery stores or access to other healthy food resources.

\footnotetext{
${ }^{1}$ For example, the median household incomes of USD54,844 for the Alma neighborhood, USD52,877 for Gardner, and USD38,494 for Washington are quite a bit lower than the USD76,495 average for San José as a whole.
} 
Focusing our programs in these neighborhoods made sense because of the less than optimal food environment, and also because of SCU's longstanding relationships in these communities. At SCU, the Ignatian Center's Arrupe Partnerships for Community-based Learning ${ }^{2}$ has sent Santa Clara students into these neighborhoods since the 1980s. Arrupe's reputation with community partners allowed us to build upon already established trust relationships to get community buy-in to start BUG programs. Developing more place-based initiatives in these neighborhoods where SCU would have a more intentional relationship and a greater impact (both on the San José and SCU communities) has been a long-time goal of Arrupe Partnerships (L. Laird, director of Arrupe Partnerships for Community Based Learning, personal communication, Nov. 2011).

The BUG program started in 2009 at the same time SCU initiated a core requirement of experiential learning for social justice. ${ }^{3}$ This new requirement meant that all SCU students had to have a placement in a community where they would explore issues of social justice such as power, privilege, and oppression. The creation of this requirement clearly reflected the Jesuit mission of educating students in solidarity with the poor and oppressed. The timing of this was fortuitous for the BUG initiative. Various university entities, seeing that many more community placements were needed to enable students to fulfill this new core curriculum requirement, were willing to support BUG programming, particularly funding the salaries of our AmeriCorps volunteers who worked in both the Forge campus garden and the community. This influx of funding and interest around food issues energized many students to become more involved with both our campus garden and community outreach programs. As a result, BUG placements have become popular with students. In 2011, more than 100 students (out of a total of 1,200 at $\mathrm{SCU}$ ) worked in BUG programs to meet

\footnotetext{
${ }^{2}$ For more information about Arrupe Partnerships, see http://www.scu.edu/ignatiancenter/students/arrupe/

${ }^{3}$ For more information about SCU's experiential learning for social justice core requirement, see

http://www.scu.edu/provost/ugst/core2009/elsj/
}

their experiential learning for social justice core requirements.

This essay will reflect on Santa Clara University's forays into experiential learning around food justice through the BUG program. We will first explore Jesuit education and experiential learning, particularly around issues of social justice. After describing the evolution of the BUG program, we focus on several observations, challenges, and questions emerging out of our experiences with BUG. Some of those observations involve the challenges of working with students and community partners to serve the interests of both groups. We also explore what food justice means to our undergraduate students and what it means when a program expands beyond the committed few to an entire student body. We find that community engagement around food justice is markedly different than the typical "food movement" experience that students working in an organic garden or farm on campus might have. Student farms around the United States tend to be more engaged with hand-on experiences of growing and marketing organic food (Sayre \& Clark, 2011) rather than the lack of access to healthy food in low-income communities of color. One of the critiques of the food movement is that it has not engaged enough with communities of color, particularly around the intersection of food access, race, and inequality (Alkon \& Agyeman, 2011). By going off campus, our students are getting to see some of the challenges that local low-income communities of color face around food system inequality and how these are linked to broader economic and social inequalities. Our students tend to be ethnically diverse ${ }^{4}$ but economically privileged. While they may feel cultural connections with the communities in which they serve, they are often coming to this experience from a position of relative privilege.

\section{Social Justice and Experiential Learning} A phrase one often hears on a Jesuit campus is that students must let the "gritty reality" of the world into their lives in order to think critically about

\footnotetext{
${ }^{4}$ Approximately 40 percent of the SCU student body are students of color. For student demographics, see http://www.scu.edu/ugrad/apply/freshman/class-profile.cfm
} 
constructive engagement. In the words of PeterHans Kolvenbach (2000, p. 8), the former superior general of the Jesuit order, students should "learn to perceive, think, judge, choose, and act for the rights of others, especially the disadvantaged and the oppressed." Jesuit education values experience, reflection, and action: experience to contextualize formal learning, reflection to understand experiences, and action that moves us beyond knowledge and understanding. SCU students have many ways of engaging with social justice activism, from student-run organizations to short- and long-term immersions, both domestically and internationally. This Jesuit value also mirrors some of the key thoughts presented by service-learning proponents John Dewey and Paulo Friere, both of whom emphasized sound integration of thought and action (Giles \& Eyler, 1994). According to Freire, true "action-reflection" safeguards us against either extreme of empty words or thoughtless behavior and leads us on a path toward changing the socioeconomic structures that engender oppression (Deans 1999).

The potential benefits of experiential learning in university settings are extensive. A 2008 report by the American Association of Colleges and Universities (AAC\&U) pinpoints field-based experiential learning with community partners as one of 10 high-impact educational practices (Kuh, 2008). The benefits can be multifaceted. Students can apply classroom knowledge in real-world settings while working for positive change in the community, and then bring this knowledge back to the classroom to critically reflect on service experiences (Kuh). Experiential learning, particularly when guided by discussions with faculty, staff, and peers, can help students question "assumptions, analyses, conclusions and actions" (AAC\&U, 2007, p. 47). Additionally, they may help to deepen the understanding of material covered in courses, increase critical thinking in complex and ambiguous situations, and show students how to engage in lifelong learning (Eyler, 2009). However, unless proper time and attention are given to integrating outside learning experiences with the goals and objectives outlined in course syllabi, students may not make appropriate connections (Qualters, 2010). Faculty must not only subscribe to the value of experiential learning from a philosophical perspective, but also be willing to take practical steps to incorporate it into their pedagogy. When these two halves are brought together, experiential learning can bear fruit. Reflecting on her BUG placement at the Alma Community Center, one SCU student stated, "it provides real insight into issues concerning poverty and immigration. I am experiencing firsthand some of the issues that we discuss in class."

Part of the experiential learning for social justice process is putting students in situations with which they may not be comfortable. Speaking about the experience of overcoming her discomfort in her BUG placement, one SCU freshman shared, "I have never done this kind of service before. I was a little apprehensive about the people at first, especially when at orientation they told us we could not wear the colors blue or red because of the gang affiliations. But the kids were great, and they love interacting with us, the Santa Clara students." She then added that her "placement pushes me into a culture that I wasn't expecting. When I signed up I didn't know what to assume about the different cultural setting. It's helped remind me that what you see on the surface isn't what is really there." Helping students to recognize the social reality of injustices in contemporary societies, including a realization of their relative privilege and the marginalization of others, is an important part of the learning experience. There is also an expectation that students will gain perspective through interactions that are appropriate, sensitive, and self-critical. Through these experiences, students should also gain an appreciation of the formal and informal knowledge, wisdom, and skills of the population with which they are working. This sort of experiential learning falls into what Mitchell (2008) calls "critical" approaches to service-learning. These experiences differ from traditional service-learning in that they foster par-

\footnotetext{
${ }^{5}$ Quotes from students are from evaluations conducted by the Arrupe Partnerships for Community-based Learning after their placements were finished. They are used by Arrupe staff to work with community partners to improve placements and to gauge the appropriateness of placements. Faculty also evaluate student experiences as part of the class evaluation experience.
} 
ticipating in social change orientations and help students to pay special attention to power, inequality, and privilege, developing authentic relationships between students and community members.

Service-learning programs are on the rise nationwide, but a flag of caution has been raised regarding placing too much emphasis on the benefits to students without ensuring that these do not come at the cost of the communities being "served" (Cone \& Harris, 1996). True servicelearning is effective only when it addresses the needs and acknowledges the worth of both students and the community. Embedded within the missions of both the experiential learning for social justice component of SCU's core curriculum and the BUG program are commitments to serving the actual needs of our neighbors. The principal motivation behind this kind of programming is to engage students and community members in a mutually beneficial relationship.

How then might we ensure that the ideas and theoretical benefits of service-learning are translated into reality? Cone and Harris (1996) offer a service-learning model that attempts to take this tension into account. The model begins with highlighting the importance of adequately preparing each student for the service-learning experience and challenging him or her to learn from it. From the faculty perspective, this entails knowing the audience and adjusting the program accordingly. How faculty approach this often depends on the particular socioeconomic and ethnic milieu their students are working in. For example, like many schools in California, our student body is fairly ethnically diverse. Students may be used to ethnic diversity, but less comfortable with extreme poverty or the undocumented status of our program participants. For instance, if the majority of students in a given class share a privileged background, this can and should inform the way they are prepared for an inner-city experience. This often adds to a faculty member's workload, and unless the faculty member is committed to the value of service-learning and well versed in its complexity, achieving successful facilitation can be difficult. A survey of faculty regarding their ability to integrate service-learning into the curriculum of their discipline showed that by and large, they were not sure how to accomplish this task (Harkavy \& Hartley, 2010). Asking students to go into communities and learn through experience can be counterproductive, as simply experiencing a different situation does not automatically lead to understanding and can even confirm previous worldviews and stereotypes (Cone \& Harris, 1996). Educators, therefore, should aid students in connecting their direct observations with abstract concepts covered in their courses through mediated and structured reflection and discussion. The instructor should facilitate learning, helping students to process what they see in communities. Success should be evaluated by the increased capacity of students to think critically and communicate articulately about their community experience (Cone \& Harris).

\section{The Program Model: BUG in the Field}

The BUG program, founded in 2009, emerged out of our campus garden, the Forge. The Forge was founded in 2007 on a university-owned lot that had previously been a dumping ground for construction material. The Forge was initially envisioned as a campus education garden, where classes could hold labs and students could learn about urban agriculture. The mission of the garden changed when we became part of a south San Francisco Bay Area collaborative, the Health Corps, which is an AmeriCorps partnership dedicated to increasing access to fresh fruits, vegetables and garden-based education to low-income residents of Santa Clara County. Becoming part of the Health Corps meant that we needed to extend our programming to engage community members rather than just SCU students. BUG currently has two broad but interrelated goals. The first is to enhance ecological literacy and community health through garden-, food-, and nutrition-based education and training programs serving children, youth, teachers, families, and seniors in marginalized communities. The second is to provide community-based learning opportunities related to environmental and food justice for Santa Clara University students. To meet these goals, we initiated programming at the Forge and two community sites: (1) a school garden and corresponding education programs primarily at Gardner Elementary School and other schools in 
the downtown area of San José, and (2) an afterschool program at the Alma Community Center that offers a combination of garden-based learning, homework assistance and enrichment activities, and mentoring to students living in a marginalized community.

The Forge and BUG remain tightly linked. The Forge is our main garden and is used for gardenbased education, training, and food production, while BUG does programming with our community partners at the Forge as well as in the community. The Forge has benefited significantly from our community engagement; our internal ${ }^{6}$ and external funding for BUG programs have helped to build out Forge garden infrastructure. Of our four full-time AmeriCorps volunteers, two are placed at the Forge and two at our community sites. However, they regularly have work exchanges at each of the sites and see each other as part of a larger team.

Students engage with the BUG program sites in many ways. Some of our students are part-time AmeriCorps volunteers; others engage with programs as interns. Most of our students, however, encounter BUG through the Arrupe Partnerships for Community-based Learning. Arrupe staff work with community partners to create placements for students. Figure 1 illustrates the Arrupe model of community-based learning that involves Arrupe staff, faculty, and community partners, all working together to engage our students in community service. Students generally participate in these experiences as part of a class requirement, although some do so independently. Arrupe placements are the most common way that SCU students meet their experiential learning for social justice core curriculum requirement. Professors wanting to incorporate this experience into a class must have their syllabi vetted and approved by a faculty committee that ensures that the class integrates the community experience through reflections and assignments. Professors then work with Arrupe Partnerships to choose appropriate placements for

\footnotetext{
${ }^{6}$ Our programs are currently funded by three on-campus entities: the dean's office of the College of Arts and Sciences, the Ignatian Center for Jesuit Education, and the Food and Agribusiness Institute.
}

their classes. Most of the available placements involve schools, daycare centers, homeless shelters, and various care facilities. There are placements at several food pantries, but BUG is the only placement that focuses on garden-based education.

Students in classes are asked to complete 16 hours of service during the course of a quarter. After a short orientation, eight-week placements begin during the third week of the 10-week academic quarter. Students are evaluated by their attendance at their community placements and through reflective exercises and projects that incorporate their service experiences into their coursework. While some students choose a placement with our programs because they have heard of the BUG program and are interested in issues of food justice, others have little experience with gardening or food systems and choose a placement because it fits into their schedule.

Our largest BUG placement is at the Alma Verde after-school program, based at a community center in the Alma neighborhood in San José. The program has hosted students from classes ranging from Teaching the Performing Arts to Environmental and Food Justice to Developmental Psychology to Solidarity in the Community. The garden at Alma is an education garden, rather than a production garden. Our programs at Alma are much more geared toward developing and encouraging healthy eating and providing environmentally focused education. We serve healthy snacks to our program participants and during the 2010 school year held a weekly farm stand based out of the Alma Community Center. Over the 2011-12 school year we have been developing relationships with local grocers to deliver foods to supplement our snack supplies. Our other sites are more garden-oriented. Volunteers at our Gardner site have built a garden and teach science-based curriculum out of the garden. We are currently developing an elementary school field-trip program out of the Forge campus garden.

Professors and staff are co-educators for our university students both in the community and the classroom. SCU students engage with children, their families, and other community members in their placements and then relate their experiences back to their classes through reflection papers, 


\section{Figure 1. Community-based Learning: The Partnerships}

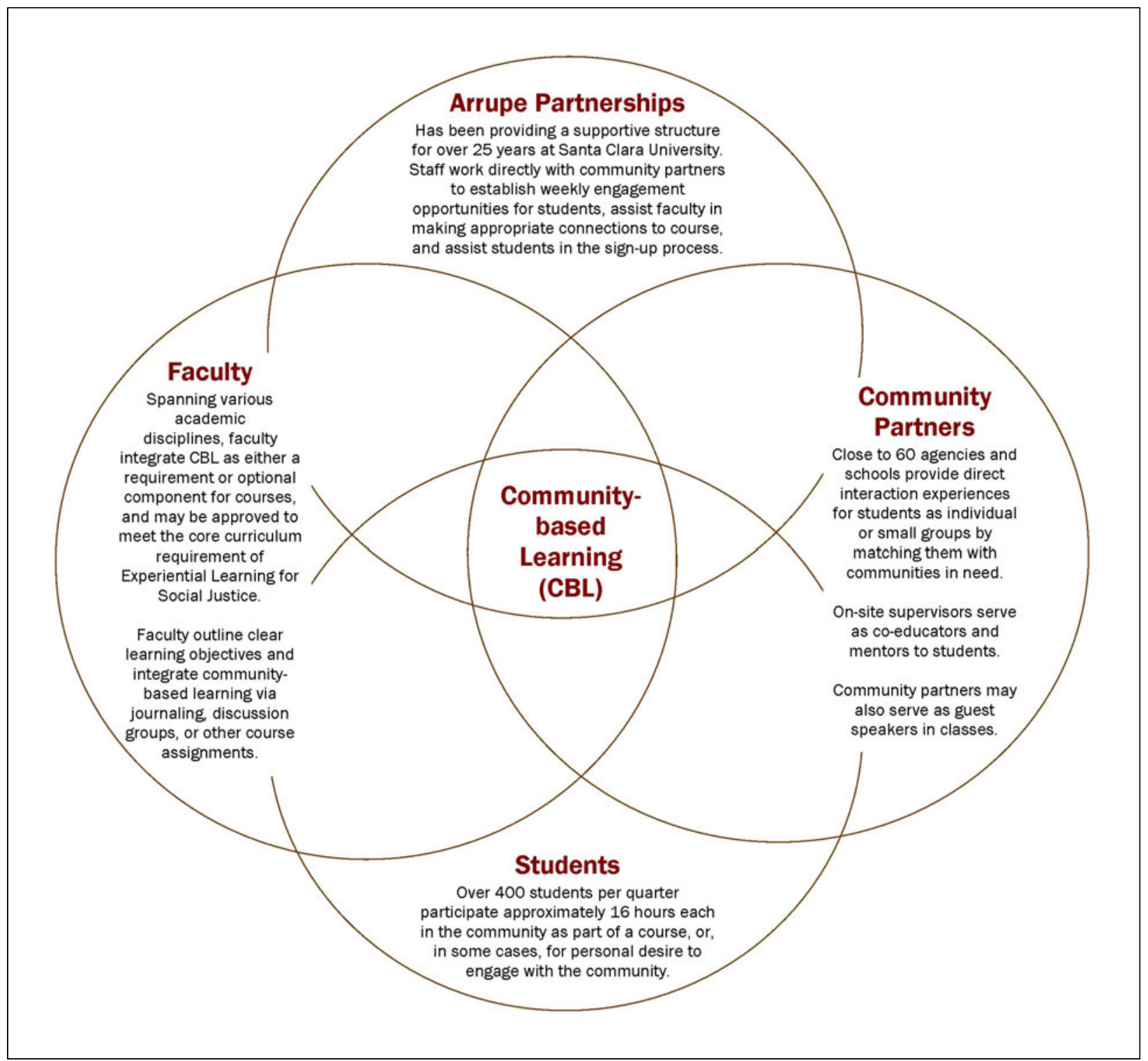

Sources: Arrupe Partnerships for Community-based Learning; Ignatian Center for Jesuit Education, Santa Clara University (2012)

journaling, and presentations. Some professors require students to implement a project, such as teaching a lesson. We find that exposure to food and agriculture is very humbling and can be transformative for college students. As one SCU student recognized of her BUG placement, "I get to interact with a community much different than what I am used to here at Santa Clara." Another student placed with BUG explained that, "it exposed a culture that I have previously not experienced." SCU students at Alma Verde often approach BUG staff to discuss how shocked they are upon learning about the kind of food program participants eat at home and to share ideas they have for bringing about change. An SCU student placed with BUG noted, "I'm in a food justice class. By working at Alma Verde, I learn how food insecurity affects the children in that area in terms of what kinds of food they're eating." Realizing that these neighborhoods have few grocery stores 
or that families do not have the financial resources to purchase healthy food comes as a surprise. Students often want to jump in and try to solve perceived problems with little understanding of the social and political constraints and root causes of inequality facing community members. Students frequently champion the idea of growing food locally, but their relative power positions are turned upside down when they realize they cannot solve community problems. Our goal is for students to realize that their experience is characterized by mutual exchange. Instead of viewing their placement as a one-way flow of service in the form of volunteering, students do often recognize that they are receiving just as much or more from the community through increased self-awareness, cultural education, and language skills. A junior placed at Gardner Elementary School explained she felt she learned more than the students she was teaching: "I chose this placement to work in a garden outside while simultaneously teaching kids all about the garden and its causes! I get sunlight, dirt under my nails, I get to have fun with a group of awesome kids, practice my Spanish, and learn probably more than the rest of the kids!"

\section{Serving Both Community and Campus Needs: Lessons Learned}

Opening up our outreach programs to serve both campus and community needs has both benefits and challenges. One of the benefits has been access to large amounts of student assistance for our program staff. This has been invaluable, particularly at Alma Verde, where SCU students work one-on-one with children, helping with homework and other enrichment activities. Our program staff are always cognizant that they are serving multiple partners and stakeholders, including local nonprofit organizations, AmeriCorps, Santa Clara University, and families. Our AmeriCorps staff positions are funded through AmeriCorps, local nonprofit The Health Trust, and Santa Clara University. Our staff have to report to both AmeriCorps and SCU and are accountable to our community partners. This requires striking a delicate balance between needs and goals of our funders, partners, and community members. This often adds a layer of complexity in terms of program management. For example, the goal of the Silicon Valley Health Corps is to increase the consumption of healthy fruits and vegetables among children and youth in Santa Clara County. Santa Clara University's goal is to cultivate the understanding of social justice among its student body. While these goals by no means stand in opposition to one another, they do represent different areas of emphasis and demand a creative approach to program implementation. These differences are also illustrated by how we measure success. AmeriCorps defines success in terms of pounds of produce grown, the number of gardens created, the number of children and adults served, and the number of classes and leadership programs conducted by our programs. The university, while aligned with the food-justice outreach mission, sees the primary metrics of success in terms of numbers of SCU students serving in the community through community-based learning opportunities, and the quality of experiences of students at their placements. Students evaluate both the quality of their placements through Arrupe and their professors in the courses they are taking for the Arrupe placement.

Besides university-community partner relationships, we must also consider the needs and wishes of the parents and students participating in BUG programs. At our Alma Community Center site, the BUG commitment to provide garden-based education often pushes up against the needs of participating families. Most of the children enrolled in Alma Verde come from Spanish-speaking families. Because many program parents do not speak English, if children do not complete their homework at the community center, they may not be able to receive help at home to finish it. Furthermore, many children at Alma Verde are several grade levels behind in math and literacy, so it takes additional time for them to complete their homework. For these reasons, parents repeatedly ask that their children's homework be completed by the time they go home. This often means that there is little time to lead a lesson in the garden. As one of our SCU student AmeriCorps volunteers noted: "It is hard when you have a group of diverse ages and abilities, like our one-room schoolhouse that makes it difficult to figure out what to teach and how to teach it. And with so 
many groups with a vested interest in our program and our programming, it's hard to please everybody." Garden education often receives short shrift in this rush to meet the needs of students.

In addition to this, we have experienced challenges with our community partners as well. Our staff has spent many hours working with community members to gain their trust and participation. Nonetheless, negotiating the fine line between responsibilities has led to misunderstandings. At Alma, for example, our partners have sometimes had different expectations about what the garden should look like. Frustration caused by misunderstandings and miscommunications has even led to the dismantling and removal of garden projects, such as square-foot gardens, tomato cages, and vegetation and produce. We learned from this experience that including the community in a participatory design process is essential to avoiding miscommunications regarding differing expectations. At our Gardner Elementary School site, the community was brought in early in the design and development process, and these sorts of problems were avoided. Despite these misunderstandings, low-income communities have generally been pleased that local university students and AmeriCorps volunteers stepped in to provide much needed services to their underserved communities.

How does this experiment in experiential learning for food justice work out for SCU students? Sending undergraduates out into the community is not the same thing as making sure they are having meaningful experiences. This is particularly true as our programs have moved beyond the committed few to encompass the whole student body. One challenge is with students who view their placement as a mandatory requirement. A few students have been vocal in their disinterest, but the majority attest to experiencing the transformative effects that the programs are intended to have. While our students do not always look different than the people in the communities they are serving, their position of privilege and power as students at an elite private school puts them in a different place, irrespective of their background. An important part of a meaningful experience relies on the coupling of the community engagement with reflection. Community engagement in a "critical" experiential learning placement around food justice navigates race, class, selfrealization, and reflection. Much of this happens formally in a classroom setting, where faculty and staff guide students through journaling, reflection, discussion, and discernment of their "positionality"

\section{Reflection on Alma Community Center}

Michelle Tang, SCU Junior and AmeriCorps Member

My connection to Alma has always felt special, I think, because I am from San José and I can bike to the center from my house in about 15 minutes! Alma Community Center is across the street from the Department of Motor Vehicles, where I got my driver's license when I was 16 years old. As a Vietnamese-American woman, I may not relate instantly to the children, who are primarily Latino, but I can usually find ways around this. Being so close to the Santa Clara campus, I think it surprises our volunteers to learn about the reality of lives in the Alma neighborhood, just fifteen minutes away from our pristine campus. But after spending eight weeks at Alma Verde, I think many of them have enjoyed learning and laughing with the kids and have added Alma Verde to their mental map. They might even find that the two hour-a-week community-based learning placement, instead of being a chore, is a chance to connect themselves and what they have been discussing in their classrooms to the lives of local kids.

Serving at Alma during my time in college has definitely been a great influence on my life. I've learned so much about gardening, about food, about nutrition, and having the opportunity to apply this in the urban setting of San José, my hometown, has been both challenging and enriching. I think I never noticed how difficult it really is to have access to healthy food growing up, although I do notice the lack of healthy food resources within walking distance. This problem is exacerbated for many of our families in the program who live in apartments, and have little to no access to a small plot of land to grow their own food. I didn't learn about "food justice" until I was in college, and spending so much time at Alma, healthy food is really hard to come by sometimes when you are looking for food here. It's a serious issue, and I think our program is only one avenue by which we can serve the local community by engaging children about nutrition, which starts at our program and can continue into their homes. 
regarding their engagements with community members. (See sidebar.) It also happens informally, as AmeriCorps staff and student interns interact with SCU volunteers. These interactions, both within and outside of a class setting, help students to process their complex feelings and experiences.

What has been an experiment in experiential learning for food justice has provided many learning moments for our faculty and staff. We have found that this endeavor of engaging local communities around food justice while using experiential learning placements to educate our own students about food justice issues has required a complex set of resources, time, and patience. We are always conscious of the delicate balance of community versus university needs, recognizing how tempting it can be to tilt in the favor of the university. All of us agree that community needs must come first; our primary program mandate is to provide garden-based education to underserved communities. In general, we have found that engaging with issues of food justice at the community level and receiving hands-on learning about sustainable agriculture has been incredibly powerful for all of our stakeholders. University students often come back transformed about their place in a very complex food system. Communities have benefited as well. One concrete benefit is that BUG has helped keep programs at the Alma Community Center afloat while the city of San José has struggled to find funds to keep it open. Furthermore, through the creation of a garden at Alma and at local elementary schools, BUG has increased awareness of and access to healthy food in one of the most impoverished areas of San José. As one parent noted one afternoon at Alma, "I think it's really great what you all do with the kids, giving them fruits and vegetables and teaching them about being healthy."

\section{Final Thoughts on Experiential Learning for Food Justice}

In this essay, we explore our attempt at using our university garden as a launching pad for an experiential learning for food justice program. We see that experiential learning in the context of food justice and garden education can successfully provide opportunities for undergraduate students to engage with marginalized communities and explore issues of social justice, while also providing a space to learn how to grow food sustainably with community members. We also believe that university garden programs can both promote community-based learning initiatives and provide low-income communities with education and services around nutrition and sustainable agriculture techniques. However, few documented programs serve as a model for a food systems approach to this type of university-community collaboration.

We come out of our recent experiences with several programmatic thoughts. Students' experiences of food systems are often very different offcampus than on-campus, particularly if they are engaging with low-income communities of color. For example, many universities have students farms that provide educational training in organic and sustainable agriculture techniques, marketing, and management (Parr \& Van Horn, n.d.). Issues such as food access and inequitable distribution of resources are not issues at the forefront of most university gardens and farms. These types of "critical" experiential learning placements expose students to a different kind of food movement that goes beyond the promotion of sustainable agriculture and organic food to issues of racial, environmental, and economic justice (Alkon \& Agyeman, 2011). However, to ensure that students engage with the community in a deep and thoughtful manner, we concur with the dominant literature emphasizing that bringing back community experiences into class settings is extremely important for learners to critically reflect and process their experience (Cone \& Harris, 1996). We have also seen that university students engaging in gardenand food-based experiential learning for the first time need to be provided with orientations to sensitize them to the issues of power, privilege, and respectful engagement before they enter into community settings.

Our engagement with experiential learning for food justice has helped us reflect on the nature of university-community partnerships. Mitchell (2008) argues that the difference between traditional and critical experiential learning is that traditional experiential learning has tended to privilege the 
needs of students over community members, whereas critical experiential learning seeks to benefit all parties. Our experiences have shown us that to benefit and support the students and communities we serve, careful coordination with communities members is a crucial step in engaging communities in meaningful ways. By doing the community-building groundwork, we have been able to develop and coordinate appropriate and effective activities, classes, and learning experiences for the community and our students. This has been an extremely time-consuming but ultimately necessary endeavor. Program faculty and staff have attended neighborhood association meetings, city council meetings, and community events, working with community members to engage in participatory design of our gardens and garden programs. We have learned the hard way that without community support and engagement, many garden programs struggle to expand or fail. When a community supports programming, garden programs can be run effectively and smoothly, benefiting not only our students but also the communities where we work.

\section{Acknowledgements}

We would like to thank Laurie Laird, Andrea Brewster, and Phyllis Brown for their helpful suggestions.

\section{References}

Alkon, A. H., \& Agyeman, J. (2011). Cultivating food justice: Race, class and sustainability. Cambridge, Massachusetts: The MIT Press.

Association of American Colleges and Universities [AAC\&U]. (2007). College learning for the new global century: A report from the National Leadership Council for Liberal Education and America's Promise. Washington, D.C.: Author.

California Food Policy Advocates. (2012). 2010 Santa Clara County Nutrition and Food Insecurity Profile. Retrieved from http://cfpa.net/GeneralNutrition/ CFPAPublications/CountyProfiles/2010/County Profile-SantaClara-2010.pdf

Cone, D., \& Harris, S. (1996). Service-learning practice: A theoretical framework. Michigan Journal of

Community Service Learning, 3(1), 31-43. http://hdl.handle.net/2027/spo.3239521.0003.104
Deans, T. (1999). Service-learning in two keys: Paulo Freire's critical pedagogy in relation to John Dewey's pragmatism. Michigan Journal of Community Service Learning, 6(1), 15-29. http://hdl.handle.net/2027/spo.3239521.0006.102

Eyler, J. (2009, Fall). The power of experiential education. Liberal Education, 95(4), 24-30.

Giles, D., \& Eyler, J. (1994). The theoretical roots of service-learning in John Dewey: Toward a theory of service learning. Michigan Journal of Community Service Learning, 1(1), 77-85. http://hdl.handle.net/2027/spo.3239521.0001.109

Gottlieb, R., \& Joshi, A. (2010). Food Justice. Cambridge, Massachusetts: The MIT Press.

Harkavy, I., \& Hartley, M. (2010). Pursuing Franklin's dream: Philosophical and historical roots of servicelearning. American Journal of Community Psychology, 46(3-4), 418-427. http://dx.doi.org/10.1007/s10464-010-9341-x

Kolvenbach, P.-H. (2000, October). The service of faith and the promotion of justice in American, Jesuit higher education [address at Santa Clara University], Santa Clara, California. Retrieved from http://www.scu.edu/ ignatiancenter/events/conferences/archives/justice Lupload/f07 kolvenbach keynote.pdf

Kuh, G. (2008). High-impact educational practices: What they are, who has access to them, and why they matter. Washington, D.C.: American Association of Colleges and Universities.

Mitchell, T. D. (2008). Traditional vs. critical servicelearning: engaging the literature to differentiate two models. Michigan Journal of Community Service Learning, 14(2), 50-65.

http://hdl.handle.net/2027/spo.3239521.0014.205

Parr, D., \& Van Horn, M. (n.d.). Sustainable Agriculture Education Association: Student farms Retrieved February 7, 2012, from http://sustainableaged.org/Topics/StudentFarms/ tabid/84/Default.aspx

Public Health Law \& Policy [PHLP]. (2010). Healthy Food Resource Assessment: Santa Clara County. Oakland, California: ChangeLab Solutions (formerly Public Health Law \& Policy). Retrieved from http://www.healthtrust.org/foodaccess/

Qualters, D. M. (2010). Making the most of learning outside the classroom. New Directions for Teaching and Learning, 2010(124), 95-99. http://dx.doi.org/10.1002/tl.427

Sayre, L., \& Clark, S. (Eds.). (2011). Fields of learning: The student farm movement in North America. Lexington, Kentucky: The University Press of Kentucky. 